Vol. 47

DOI:10.37190/epe210102

\title{
CHANGE OF PHYSICHOCHEMICAL PROPERTIES AND HEAVY METALS CONTENT IN SEWAGE SLUDGE DURING ITS VERMICOMPOSTING WITH EISENIA FETIDA
}

\begin{abstract}
This study aimed to evaluate the vermicompost quality of sewage sludge (SS) mixed with sugar beet pulp (SBP) and cow dung (CD) wastes employing Eisenia fetida. The basic issue faced in the wastewater treatment plant is how to reduce the amount of sewage sludge? This paper discusses an in-situ vermicomposting approach for the reuse of sewage sludge. A total of 11 reactors containing various waste combinations were organized and changes in physicochemical parameters were evaluated during 90 days of the experiment. The results indicated that SS could be converted into a good quality product by vermicomposting if suitable mixing quantities are provided (50\% SS, $25 \% \mathrm{SBP}, 25 \% \mathrm{CD})$. Vermicomposting caused significant reductions in $\mathrm{pH}$, TOC, the content of heavy metals, and $\mathrm{C} / \mathrm{N}$ ratio, while electric conductivity and NPK content increased as compared to initial mixtures. The present study implied that the application of sewage sludge in the agricultural fields after vermicomposting could be a suitable and usable approach for sewage disposal.
\end{abstract}

\section{INTRODUCTION}

Excess sewage sludge from any municipal wastewater treatment plant (WWTP) becomes a serious problem due to its increasing amount. Sewage sludge was defined by the European Parliament and Council as compulsory recycling and reusable waste [1]. Recent regulations $[2,3]$ placed the highest importance on the landfill directive, which would limit the amount of sewage sludge sent to the landfill and encourage the good environmental practice by increasing the use of sewage in agriculture [4]. Many EU countries tend to reject conventional solutions because of a decrease in the capacity of landfills and strict European Union legislation [1,5]. Sludge management is a serious problem, not only in European countries, but also in Australia [6], Latin America [7],

${ }^{1}$ Erciyes University, Department of Environmental Engineering, Kayseri, Turkey, email address: stazgin@erciyes.edu.tr 
Asian countries [8], and Turkey [9]. While the quantity of sludge depends on different factors and hence is quite variable, the nature of this sludge-rich in nutrients, but also often loaded with high concentrations of pollutants such as heavy metals has led countries to search for various alternatives for its disposal [10]. According to Eurostat data, more than $50 \%$ of EU countries still used sludge in agricultural activity. Almost seventeen countries use composting, and the countries of Estonia, Hungary, and Finland have percentages higher than $60 \%$. While the Netherlands, Germany, Slovenia, and Austria use incineration as their main disposal method, discharge into controlled landfills was used as the principal type of treatment in Malta, Croatia, Romania, and Italy as well as Serbia and Bosnia and Herzegovina [10]. Similarly, Turkey, which has candidate membership status for the EU, handle its sewage sludge by different methods. While $26 \%$ of the total sludge amount is ultimately sent to the landfill, $6 \%$ of sludge is used for agricultural purposes, [11] and the remaining quantity is used as fuel for cement production in incineration plants [9].

Keeping the above facts in mind, there is a need for an eco-friendly approach like vermicomposting that has many benefits because it is odorless, budget-friendly, free of toxic waste, and results in a valuable end product, a way to deal with the increasing sewage problem [12]. Vermicomposting is a biological process based on interactions between earthworms and microorganisms that adequately convert different types of organic wastes into a soil improver [13]. It is the least expensive method and requires less labor and time, and the resulting product is of good quality and has a high market value. Recently, vermicomposting has become a popular transformation method by introducing earthworms into the compost $[14,15]$. Recently, many studies have been conducted in the vermicomposting of varied mixtures including sewage sludge and different types of organic wastes $[12,16,17]$; some studies investigated the effect of the $\mathrm{C} / \mathrm{N}$ ratio during the vermicomposting of sewage sludge. Changes in the toxicity of the sewage sludge by vermicomposting processes reported by Zhu et al. [18]. However, there is no consensus in the scientific literature that vermicomposting increases or decreases the concentration of heavy metals in organic waste residuals like sewage sludge and other organic materials $[19,20]$. Based on the available literature, investigations of combining sugar cane or sugar beet pulp with sewage sludge to obtain a rich soil improver are very limited [21]. Sugar industry waste like beet pulp contains organic carbon, sugars, proteins, and some enzymes in large amounts. However, the direct use of this type of fertilizer has not been tried much before [22].

To fill in the gaps mentioned above, a pilot-scale experiment design in the present study was established: (1) to evaluate the viability limit of the vermicomposting when the process is performed using sewage sludge in eleven different mixtures employing Eisenia fetida, (2) to detect changes in heavy metal concentration in the produced vermicompost, and (3) to discuss in situ vermicomposting approach for the reuse of sewage sludge. 


\section{MATERIALS AND METHODS}

Sewage sludge was obtained directly from the Kayseri biological wastewater treatment plants in the Anatolian region of Turkey. The fresh sewage sludge was dried in a drying oven, using the well-known technique operating on the moisture removal principle by evaporation [23]. Cow dung (CD) was collected from different farms, and sugar beet pulp (SBP) was obtained from the Kayseri Sugar Beet Cooperative, one of the biggest sugar processing plants in Turkey. Before the laboratory experiment, the physicochemical parameters were analyzed for each waste according to standard methods [24]. The physicochemical characteristic of the waste is given in Table 1.

Table 1

Composition of cow dung, sewage sludge, and sugar beet pulp used for vermicomposting

\begin{tabular}{|l|c|c|c|}
\hline \multicolumn{1}{|c|}{ Parameter } & Sewagesludge & Sugarbeetpulp & Cowdung \\
\hline $\mathrm{pH}$ & $6.55 \pm 0.02$ & $5.96 \pm 0.04$ & $8.80 \pm 0.02$ \\
\hline $\mathrm{EC}, \mathrm{dS} / \mathrm{m}$ & $0.57 \pm 0.01$ & $0.97 \pm 0.02$ & $4.8 \pm 0.64$ \\
\hline Total organic carbon, wt. \% & $35 \pm 04$ & $51 \pm 09$ & $49 \pm 08$ \\
\hline Moisture, wt. \% & $24 \pm 04$ & $48 \pm 07$ & $35 \pm 03$ \\
\hline Total solids, wt. \% & $27 \pm 03$ & $55 \pm 07$ & $50 \pm 05$ \\
\hline Total nitrogen, wt. \% & $3.8 \pm 0.42$ & $0.80 \pm 0.01$ & $2.20 \pm 0.41$ \\
\hline Total phosphorous, wt. \% & $1.63 \pm 0.02$ & $0.58 \pm 0.01$ & $0.41 \pm 0.01$ \\
\hline $\mathrm{C}: \mathrm{N}$ ratio & $9.21 \pm 2.55$ & $63.75 \pm 6.48$ & $22 \pm 3.47$ \\
\hline $\mathrm{Pb}, \mathrm{mg} / \mathrm{kg}$ & $177 \pm 12.25$ & - & - \\
\hline $\mathrm{Cr}, \mathrm{mg} / \mathrm{kg}$ & $180 \pm 11.34$ & - & - \\
\hline $\mathrm{Cu}, \mathrm{mg} / \mathrm{kg}$ & $111 \pm 14.55$ & - & - \\
\hline $\mathrm{Hg}, \mathrm{mg} / \mathrm{kg}$ & $0,36 \pm 0.04$ & - & - \\
\hline
\end{tabular}

Experimental set-up. The earthworm E. fetida was chosen for the experiment. 11 vermicomposting reactors (Fig. 1) made of plastic boxes $(27 \times 19 \times 8 \mathrm{~cm})$ were filled with different waste mixtures (Table 2). Each reactor contained $500 \mathrm{~g}$ of waste mixtures
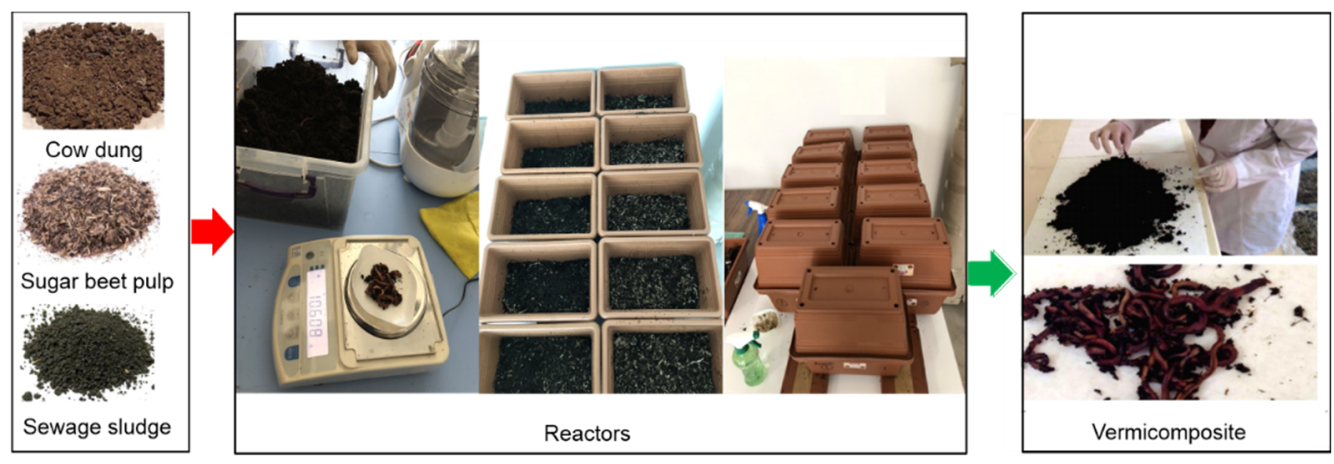

Fig. 1. Laboratory design for vermicompost 
on a dry weight basis. All reactors were drilled on the bottom. They were kept in the dark at $23 \pm 2{ }^{\circ} \mathrm{C}$ (by controlling with a central air conditioner). The moisture content was kept at $65-75$ wt. \% by sprinkling distilled water throughout the study period. Vermicomposting process was evaluated after 15,30,45, and 60 days by measuring selected physical and chemical parameters to check vital condition of the earthworms. Analyses were done according to the methods described in the next section.

Table 2

Composition of dry waste mixtures in reactors [\%]

\begin{tabular}{|c|c|c|c|}
\hline Reactor & Sewage sludge & Cow dung & Sugar beet pulp \\
\hline 1 & - & 50 & 50 \\
\hline 2 & 10 & 45 & 45 \\
\hline 3 & 20 & 40 & 40 \\
\hline 4 & 30 & 35 & 35 \\
\hline 5 & 40 & 30 & 30 \\
\hline 6 & 50 & 25 & 25 \\
\hline 7 & 60 & 20 & 20 \\
\hline 8 & 70 & 15 & 15 \\
\hline 9 & 80 & 10 & 10 \\
\hline 10 & 90 & 5 & 5 \\
\hline 11 & 100 & - & - \\
\hline
\end{tabular}

Physicochemical analyses. Before analysis, approximately $150 \mathrm{~g}$ of the homogenized reactor contents that were air-dried in the dark at room temperature and blended were collected from the reactors. $\mathrm{pH}$ and $\mathrm{EC}$ were determined in all samples diluted in double distilled water at a proportion of 1:10 (w/v). Phosphorus content was determined using a spectrophotometer (Hach Lange DR 5000 UV-VIS) following the APHA procedures [25]. TOC and TN were determined by catalytic thermal decomposition methods using total organic carbon and total nitrogen analyzer (TNM-L, Shimadzu, Japan). The $\mathrm{C} / \mathrm{N}$ ratio was calculated as TOC/TN. To determine the total heavy metal concentration $(\mathrm{Pb}, \mathrm{Cr}, \mathrm{Cu}, \mathrm{Ni}, \mathrm{Hg})$, the samples were analyzed using an atomic absorption spectrophotometer Perkin Elmer AAnalyst 400 AA).

Statistical analysis. The data were analyzed using a one-way analysis of variance (ANOVA) with Microsoft Excel 2010 software $(P<0.05)$ followed by Duncan's multiple range tests (DMRT) for the comparison of the means at the $\alpha=0.05$ significance level.

\section{RESULTS AND DISCUSSION}

The survival of earthworms like Eisenia fetida depends on the conditions provided in reactors. Major challenges for vermicomposting are incorrect moisture levels, temperature fluctuation, problematic air circulation, and thus the need to constantly check the system. 
To determine the survival status of earthworms, all reactors were checked visually, and their food (mixed waste) consumption was monitored by checking each reactor closely. The earthworms in reactors 1-6) stayed alive until the 60 day, the earthworms in the rest of the reactors (7-11) did not survive; almost all earthworms died in six to seven days.

Depending on the mixture in the reactors, changes in $\mathrm{pH}$ were observed during the vermicomposting period (60 days). The initial $\mathrm{pH}$ in reactors $1-6$ ranged from 6.60 to 7.43 , and, in the final $\mathrm{pH}$ ranged from 7.00 to 6.68 (Table 3). In reactors 7 to 11, which had a high SS concentration (SS content 60-100\%), the earthworms could not tolerate the conditions and died in a short period. The maximum decrease in $\mathrm{pH}(7 \%)$ was observed in reactor $3(20 \% \mathrm{SS}+40 \% \mathrm{CD}+40 \% \mathrm{SBP})$, and the minimum was observed in reactors $6(50 \% \mathrm{SS}+25 \% \mathrm{CD}+25 \% \mathrm{SBP})$ and $5(5 \%)$ (Fig. 2). Several studies have indicated similar $\mathrm{pH}$ trends during the vermicomposting of different mixtures $[16,26]$. The statistical decrease in $\mathrm{pH}$ for reactor 3 was significantly different from each other $(P<0.05)$. Comparative figures for the $\mathrm{pH}, \mathrm{EC}, \mathrm{TOC}, \mathrm{TN}, \mathrm{TN}$, and $\mathrm{C}: \mathrm{N}$ parameters in the waste reactors and final vermicompost are summarized in Table 3.

Table 3

Physicochemical characteristics of initial mixtures and final vermicompost

\begin{tabular}{|c|l|c|c|c|c|c|c|}
\hline \multirow{2}{*}{ Reactor } & Contents & $\mathrm{pH}$ & $\begin{array}{c}\mathrm{EC} \\
\mathrm{dS} / \mathrm{m}\end{array}$ & $\begin{array}{c}\text { TOC } \\
{[\%]}\end{array}$ & $\begin{array}{c}\text { TN } \\
{[\%]}\end{array}$ & $\begin{array}{c}\text { TP } \\
{[\%]}\end{array}$ & $\begin{array}{c}\text { C:N } \\
\text { ratio }\end{array}$ \\
\hline \multirow{2}{*}{1} & initial & $7.45 \pm 0.42$ & $2.94^{\mathrm{a}} \pm 0.03$ & $50.00 \pm 0.05$ & $1.50 \pm 0.17$ & $0.50 \pm 0.03$ & 33.30 \\
\cline { 2 - 8 } & final & $7.00 \pm 0.25$ & $3.35 \pm 0.02$ & $25.45 \pm 0.47$ & $1.70 \pm 0.86$ & $0.74 \pm 0.17$ & 15.50 \\
\hline \multirow{2}{*}{2} & initial & $7.35 \pm 0.32$ & $2.76 \pm 0.01$ & $48.54 \pm 0.07$ & $1.73 \pm 0.02$ & $0.61 \pm 0.05$ & 28.03 \\
\cline { 2 - 8 } & final & $6.94 \pm 0.61$ & $3.23 \pm 0.21$ & $24.78 \pm 0.28$ & $1.77 \pm 0.05$ & $0.87 \pm 0.10$ & 14.94 \\
\hline \multirow{2}{*}{3} & initial & $7,26 \pm 0.11$ & $2.42 \pm 0.10$ & $47.11 \pm 0.05$ & $1.96^{\mathrm{a}} \pm 0.81$ & $0.72 \pm 0.03$ & 24.00 \\
\cline { 2 - 8 } & final & $6.80^{\mathrm{a}} \pm 0.02$ & $3.00^{\mathrm{a}} \pm 0.07$ & $25.30^{\mathrm{a}} \pm 0.29$ & $2.11 \pm 1.03$ & $1.12 \pm 0.22$ & $12.44^{\mathrm{a}}$ \\
\hline \multirow{2}{*}{4} & initial & $7.18 \pm 0.54$ & $2.10 \pm 0.05$ & $45.50 \pm 0.17$ & $2.19 \pm 0.54$ & $0.84 \pm 0.11$ & 20.78 \\
\cline { 2 - 8 } & final & $6.76 \pm 0.68$ & $2.45 \pm 0.02$ & $23.45 \pm 0.39$ & $1.78^{\mathrm{a}} \pm 0.44$ & $1.58 \pm 0.24$ & 13.54 \\
\hline \multirow{2}{*}{5} & initial & $7.10 \pm 0.47$ & $1.96 \pm 0.06$ & $44.00 \pm 0.04$ & $2.42 \pm 0.27$ & $0.95 \pm 0.13$ & 18.18 \\
\cline { 2 - 8 } & final & $6.74 \pm 0.49$ & $2.20 \pm 0.10$ & $30.58^{\mathrm{a}} \pm 0.28$ & $2.46 \pm 0.57$ & $2.14 \mathrm{a} \pm 0.51$ & $12.40^{\mathrm{a}}$ \\
\hline \multirow{2}{*}{6} & initial & $7.02 \pm 0.33$ & $1.73 \pm 0.22$ & $42.52 \pm 0.05$ & $2.65 \pm 0.29$ & $1.06 \pm 0.22$ & 16.00 \\
\cline { 2 - 8 } & final & $6.70 \pm 0.21$ & $1.86 \pm 0.08$ & $32.00 \pm 0.36$ & $2.79 \pm 0.94$ & $2.31^{\mathrm{a}} \pm 0.44$ & 11.45 \\
\hline
\end{tabular}

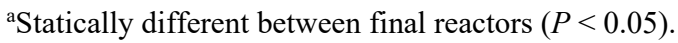

As shown in Fig. 2 and Table 3, the final EC values of all reactors were higher than in the initial mixtures. During the organic waste degradation, the release of various soluble salts and minerals might have increased the $\mathrm{EC}$ value of the reactors [19,27]. The maximum EC increase was found in reactor 3 compared to initial mixtures (24\%), but there were no significant differences observed in the EC between reactors $2,4,5$, and $6(P<0.05)$.

A decrease in TOC after the composting period was observed in all reactors similarly to that in $\mathrm{pH}$. The initial TOC content of the reactors ranged from 35 to $50 \%$, and, after the composting period, the final value of TOC decreased from 25 to $32 \%$ (Fig. 2). 

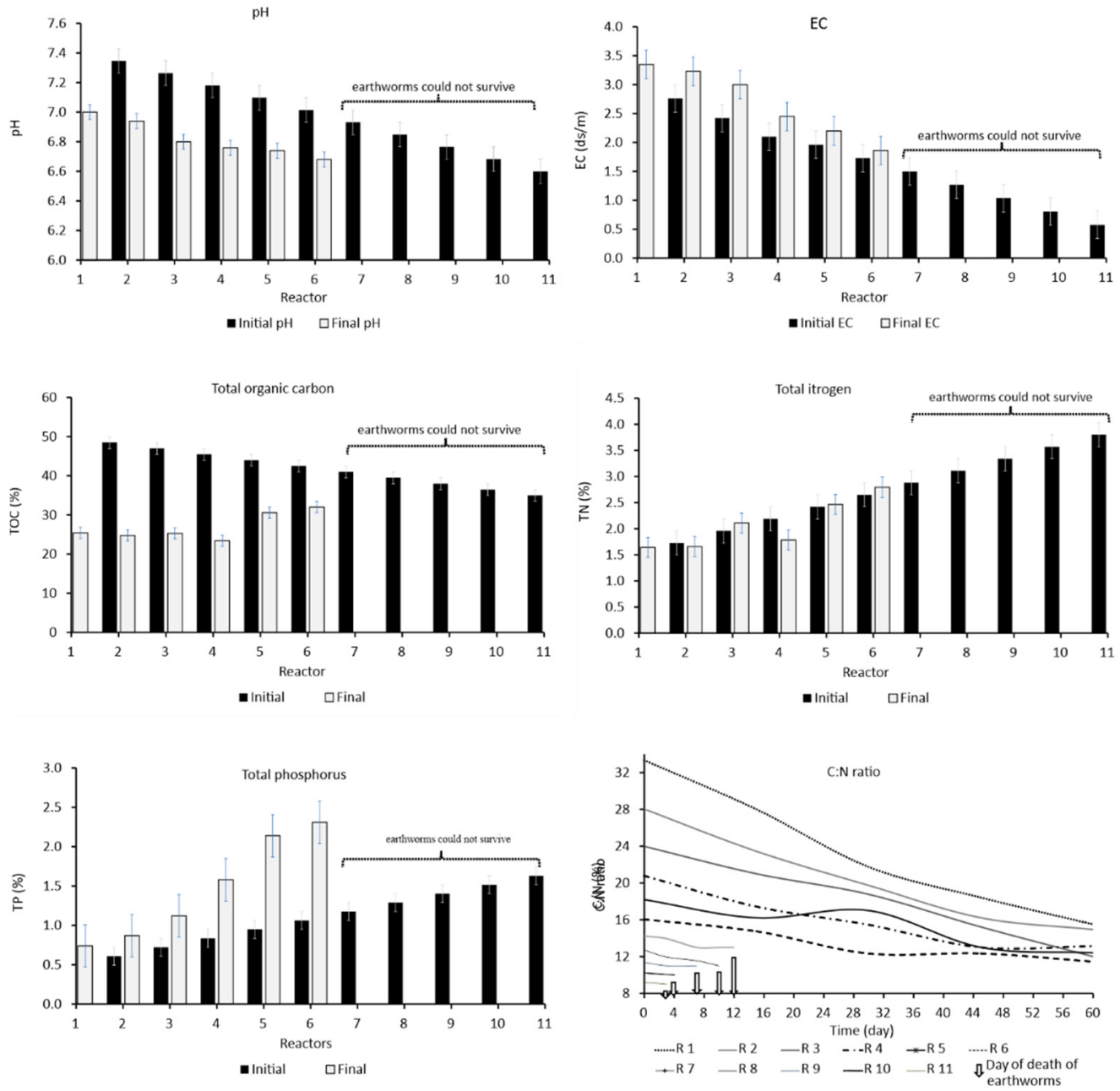

Fig. 2. Initial and final (after 60 days of vermicomposting) values of $\mathrm{pH}, \mathrm{EC}, \mathrm{TOC}, \mathrm{TN}$, and TN; variation in $\mathrm{C}: \mathrm{N}$ value within 60 days of vermicomposting

The maximum decrease was observed in reactors 1 and $2(49 \%)$, a minimum decrease - in reactor $6(25 \%)$. There is a consensus in the earlier scientific study that a decrease in TOC during the vermicomposting of different types of waste was due to the loss of carbon in the form of $\mathrm{CO}_{2}$ caused by 022 microbial respiration and the mineralization of the organic material used by the earthworms [24, 28]. There were no significant differences in the TOC values between reactors $1,2,4$, and $6(P<0.05)$. As shown in Table 3 , the increase in the TN content after vermicomposting was observed in all reactors except for reactor 4 . The $\mathrm{TN}$ concentration at the initial stage of composting ranged from 1.50 to $3.80 \%$, and, in the final vermicomposts, it ranged from 1.64 to $2.79 \%$ (Fig. 2). The 
obtained results were similar to already reported findings [28] showing an increasing trend for $\mathrm{TN}$ value during vermicomposting. The final $\mathrm{TN}$ values calculated for reactors 1 and 3 were 9 and $8 \%$ higher than their initial concentrations, respectively. A higher nitrogen concentration in the final product than in the initial mixture may be due to a reduction in organic carbon to $\mathrm{CO}_{2}$ and the release of nitrogen by the earthworms in the form of mucus $[27,28]$. The $\mathrm{C}: \mathrm{N}$ ratio is an indicator of the quality and maturity of the vermicompost; therefore, it could be used to evaluate the vermicompost quality. The $\mathrm{C}: \mathrm{N}$ ratio decreased in all reactors due to the increased $\mathrm{TN}$ concentration and the decrease in the TOC value (Fig. 2). At the end of the vermicomposting period, the C:N ratios for reactors $1-6$ ranged from 15.23 to 11.45 . While the maximum decrease was observed in reactor $1(54 \%)$, the minimum decrease rate was seen in reactor $6(29 \%)$. Sharma et al. [28] summarized the findings of most studies in terms of the decrease in the C: $N$ ratio in different organic types of waste. The total phosphorous contents were higher in the final vermicomposts than in the initial mixtures of the reactors. Initially, the phosphorous content was 0.50 and $1.63 \%$ and increased to $0.94-2.31 \%$, showing a total increase by $30-54 \%$ after vermicomposting.
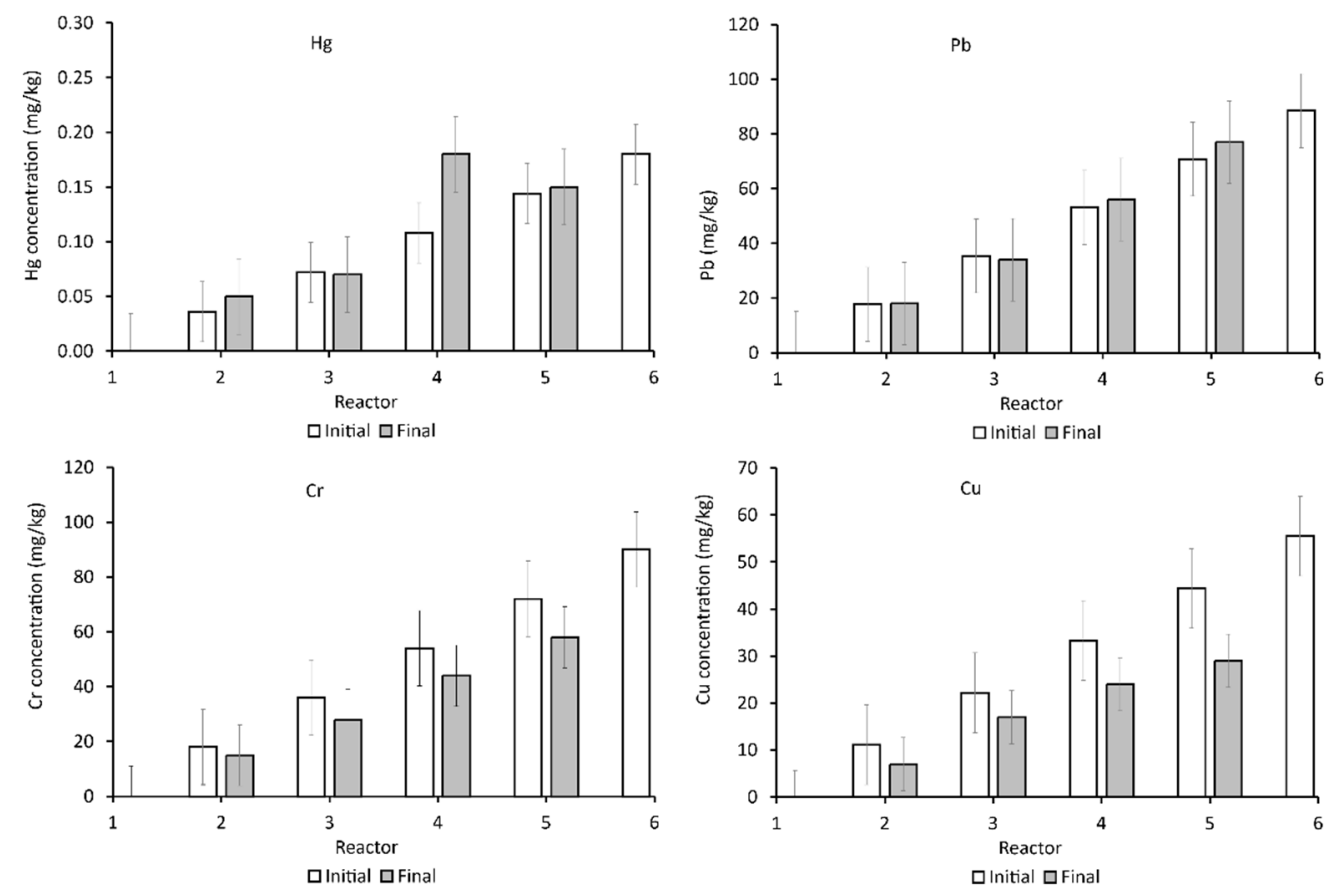

Fig. 3. Heavy metals content in initial vermicompost and final after 60 days

The heavy metal content in the vermicompost was variable depending on the physicochemical properties and the metal concentration in the waste. Zhu et al. [18] con- 
cluded that metal concentration could be changed due to various mechanisms, i.e., accumulation of heavy metals in the bodies of the worms and environmental conditions. There is no consensus that the vermicomposting process increases or decreases heavy metals concentration in the waste mixture. While several studies have indicated that the vermicompost process caused an increase in the total heavy metal content in the final vermicompost [13], other studies have indicated the reverse [20,28]. Heavy metal content was evaluated after 60 days by measuring the selected elements $\mathrm{Hg}, \mathrm{Pb}, \mathrm{Cu}$, and $\mathrm{Cr}$. Similarly, the $\mathrm{Hg}$ and $\mathrm{Pb}$ content of the final vermicompost were reported to increase compared to the initial case whereas a decrease was seen for the $\mathrm{Cu}$ and $\mathrm{Cr}$ content in all reactors (Fig. 3).
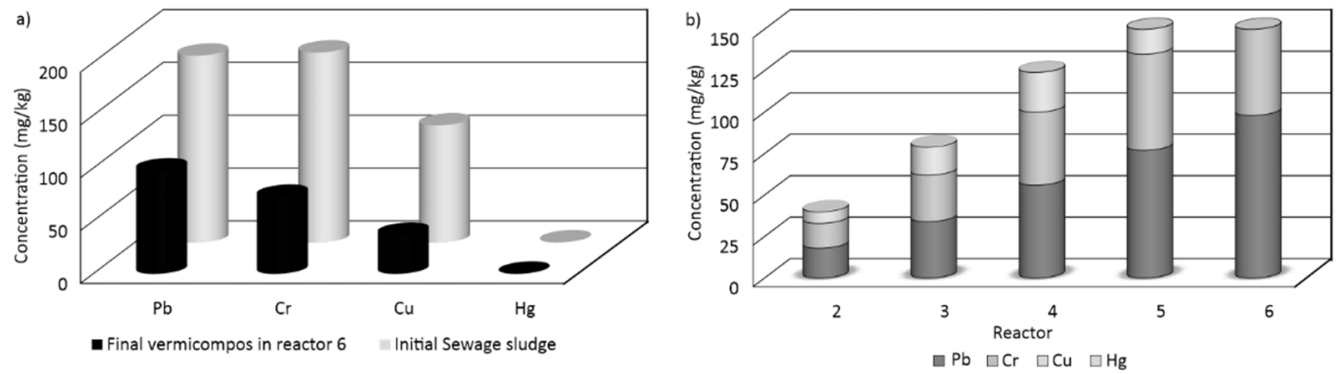

Fig. 4. Final content of heavy metals in the reactors $2-6$ (a), and heavy metal content in initial SS and final compost for reactor 6 (b)

Heavy metal content varied depending on the characteristics of the sewage sludge that was their only source for all reactors. The concentration of $\mathrm{Pb}$ varied from 18 to $177 \mathrm{mg} / \mathrm{kg}$ while that of $\mathrm{Hg}$ ranged from 0.04 to $0.36 \mathrm{mg} / \mathrm{kg}$. Except for reactors $7-11$ that had a high SS concentration resulting in a high heavy metal concentration as well, the highest contents of $\mathrm{Pb}(98 \mathrm{mg} / \mathrm{kg})$ and $\mathrm{Hg}(0.22 \mathrm{mg} / \mathrm{kg})$ were observed in reactor 6 $(50 \% \mathrm{SS}+25 \% \mathrm{CD}+25 \% \mathrm{SBP})$. As shown in Fig. 3, an increase in the total $\mathrm{Pb}$ and $\mathrm{Hg}$ was observed for all final reactors except for reactor 3 . However, when comparing the initial and final content of $\mathrm{Cu}$ and $\mathrm{Cr}$, it could be concluded that the $\mathrm{Cu}$ content was $33 \%(37 \mathrm{mg} / \mathrm{kg})$ lower in the final vermicompost. A higher $\mathrm{Cu}$ loss was also found in reactor $3(22 \%-28 \mathrm{mg} / \mathrm{kg})$ whereas the decrease rate for the other reactors was similar (19\%) (Fig. 3). The decreasing order of the heavy metal content was found to be almost the same in reactors 2-6: $\mathrm{Pb}>\mathrm{Cr}>\mathrm{Cu}>\mathrm{Hg}$ (Fig. 4). The mixture in reactor $1(50 \%$ $\mathrm{CD}+50 \% \mathrm{SBP})$ did not contain heavy metals. In our study, the possible presence of sewage sludge led to the presence of heavy metal. The mixture in reactor 6 was able to provide optimum conditions for the earthworms. The earthworms could tolerate $50 \%$ SS with $25 \% \mathrm{CD}$ and $25 \%$ SBP. The increased amount of sewage sludge in the reactors 7-11 might be toxic to the earthworms and decrease their vital activity. After 60 days, the concentration of $\mathrm{Pb}, \mathrm{Cr}, \mathrm{Cu}$, and $\mathrm{Hg}$ in reactor 6 was significantly lower compared 
to the initial sewage sludge. Total $\mathrm{Cr}$ and $\mathrm{Cu}$ content decreased by 59 and $67 \%$ in reactor 6 after vermicomposting, respectively. This suggested that optimum vermicomposting conditions could reduce the toxicity of heavy metals present in sewage sludge.

\section{CONCLUSION}

Sewage sludge requires a huge damping area, and transportation to the landfill is an economically expensive process. Sewage sludge from wastewater treatment plants contains significant amounts of nitrogen, phosphorous, and heavy metals; therefore, direct application to the agricultural area as fertilizer is not suitable nor environmentally feasible. The obtained results showed, that after mixing sewage sludge in appropriate quantities $(50 \%)$ with cow dung and sugar beet pulp, it could be used as a raw material in vermicomposting. Developing European countries like Turkey could benefit from the advantages of the vermicomposting system to deal with the disposal problem, and it could be an alternative technology for in-situ application because the end product can obtain odorless good quality fertilizer, but the change in heavy metal content should be evaluated in future research.

\section{ACKNOWLEDGEMENTS}

This study has been supported by Erciyes University Scientific Research Projects and Coordination commission (Project id: FBA-2017-6786), Turkey (Kayseri).

\section{REFERENCES}

[1] Directive 2008/1/EC of the European Parliament and of the Council of 15 January 2008 concerning integrated pollution prevention and control, Official Journal of the European Union (cited 20 December 2018), Available from https://eur-lex.europa.eu/LexUriServ/LexUriServ.do?uri=OJ:L:2008:024:0008: 0029:EN:PDF

[2] Directive 2010/75/EU of the European Parliament and of the Council of 24 November 2010 on industrial emissions (integrated pollution prevention and control) [Internet]. Official Journal of the European Union [cited 20 December 2018]. Available from https://eur-lex.europa.eu/legal-content/EN/TXT/ ?uri=CELEX\%3A32010L0075

[3] JRC Scientific and Policy Reports. Technical report for end-of-waste criteria on biodegradable waste subject to biological treatment (compost \& digestate). Hans Saveyn and Peter Eder, 2014 (cited 12 March 2019), available from http://publications.jrc.ec.europa.eu/repository/bitstream/JRC87124/eow\% 20biodegradable $\% 20$ waste $\% 20$ final\%20report.pdf

[4] Kacprzak A., Neczaj E., Fijalkowski K., Grobelak A., Grosser A., Worwag M., Rorat A., Brattebo H., Almas A., Singh B.R., Sewage sludge disposal strategies for sustainable development, Environ. Res., 2007, 156, 39-46.

[5] Mininni G., Blanch A.R., LuCEna F., Berselli S., EU policy on sewage sludge utilization and perspectives on new approaches of sludge management, Environ. Sci. Pollut. Res., 2015, 22, 7361-7374.

[6] Pritchard D.L., Penney N., McLaughlin M.J., Rigby H., Schwarz K., Land application of sewage sludge (biosolids) in Australia. Risks to the environment and food crops, Water Sci. Technol., 2010, 62, $48-57$. 
[7] DREChSEl P., QAdiR M., WiChelns D., Wastewater. Economic asset in an urbanizing world, Springer, 2015, 86-89.

[8] YANG G., ZhANG G., WANG H., Current state of sludge production, management, treatment and disposal in China, Water Res., 2015, 78, 60-73.

[9] AdAR E., KaRATOP B., INCE M., BILGILI M.S., Comparison of methods for sustainable energy management with sewage sludge in Turkey based on SWOT-FAHP analysis, Renew Sust. Energ. Rev., 2016, 62, 429-440.

[10] Eurostat 2015. Sewage sludge disposal from urban wastewater treatment, by type of treatment. Eurostat statistics explained, 2015 (cited 24 March 2019), available from https://ec.europa.eu/eurostat/statistics -explained/index.php?title=File:Sewage_sludge_disposal_from_urban_wastewater_treatment,_by_type of treatment, 2015 (\%25_of total_mass)_V2.png

[11] Turkish Statistical Institute Official Internet Site, TUIK:2014 (cited 12 May 2019), available from http://www.tuik.gov.tr/Start.do

[12] SUTHAR S., Vermicomposting of vegetable market solid waste using Eisenia foetida: impact of bulking material on earthworm growth and decomposition rate, Ecol. Eng., 2009, 35, 914-920.

[13] AMOUEI A.I., Yousefi Z., KHOSRAVi T., Comparison of vermicompost characteristics produced from sewage sludge of wood and paper industry and household solid wastes, J. Environ. Health Sci. Eng., $2017,15,5$.

[14] AdiloĞLu S., AÇıKGöz F.E., Solmaz Y., ÇAKtÜ E., AdiloĞLu A., Effect of vermicompost on the growth and yield of lettuce plant (Lactuca sativa L. var. crispa), Int. J. Plant Soil Sci., 2018, 21, 1-5.

[15] Kumar A., DhYANi B.P., RAI A., KUMAR V., Residual effect of applied vermicompost and NPK to rice on growth and yield of succeeding wheat and chemical properties of soil, Int. J. Curr. Microbiol. App. Sci., 2017, 6, 1087-1098.

[16] GuPTA R., GARG V.K., Stabilization of primary sewage sludge during vermicomposting, J. Hazard. Mater., 2008, 153, 1023-1030.

[17] Suleiman H., Rorat A., Grobelak A., Grosser A., Milczarek M., PŁytycz B., Kacprzak M., VANDENBULCKE F., Determination of the performance of vermicomposting process applied to sewage sludge by monitoring of the compost quality and immune responses in three earthworm species. Eisenia fetida, Eisenia andrei and Dendrobaena veneta, Bioresour. Technol., 2017, 241, 103-112.

[18] ZHU W., YAO W., ZHANG Z., WU Y., Heavy metal behavior and dissolved organic matter (DOM) characterization of vermicomposted pig manure amended with rice straw, Environ. Sci. Pollut. R., 2014, 21, 12684-12692.

[19] KhWAiraKPam M., Bhargava R., Vermitechnology for sewage sludge recycling, J. Hazard. Mater., 2009, 161, 948-954.

[20] Soobhany N., Preliminary evaluation of pathogenic bacteria loading on organic Municipal Solid Waste compost and vermicompost, J. Environ. Manage., 2018, 206, 763-767.

[21] Kumar R., Verma D., Singh B.L., Shweta U.K., Composting of sugar-cane waste by-products through treatment with microorganisms and subsequent vermicomposting, Bioresour. Technol., 2010, 101, 6707-6711.

[22] ZHANG L., SUN X., Influence of sugar beet pulp and paper waste as bulking agents on physical, chemical, and microbial properties during green waste composting, Bioresour. Technol., 2018, 267, 182-191.

[23] RATTI C., Hot air and freeze-drying of high-value foods. A review, J. Food Eng., 2001, 49, 311-319.

[24] LENORE S., ARNOLD E., ANDREW D.E., Standard methods for the examination of water and wastewater, 20th Ed., American Public Health Association, 1998, 5310-TOC.

[25] LENORE S., ARNOLD E., ANDREW D.E., Standard methods for the examination of water and wastewater, 20th Ed., American Public Health Association, 1998, 2510-EC.

[26] Ndegwa P.M., ThOMPSON S.A., Integrating composting and vermicomposting in the treatment of bioconversion of biosolids, Bioresour. Technol., 2001, 76, 107-112. 
[27] Tognetti C., Laos F., Mazzarino M.J., Hernandez M.T., Composting vs. vermicomposting: a comparison of end product quality, Sci. Compost. Util., 2005, 13, 6-13.

[28] SHARMA K., GARG V.K., Comparative analysis of vermicompost quality produced from rice straw and paper waste employing earthworm Eisenia fetida (Sav.), Bioresour. Technol., 2018, 250, 708-715. 